\title{
Gene EBNA3C: Type of Infection by EBV (EBV1 and EBV2) Correlation With Clinical and Biochemical Parameters (AST, ALT and GGT) in Individuals With Infectious Mononucleosis in the Metropolitan Area of Belém, Pará, 2005-2016
}

Talita Antonia Furtado Monteiro ( $\nabla$ talitamonteiro859@gmail.com )

Instituto Evandro Chagas https://orcid.org/0000-0002-2009-4062

Iran Barros Costa

Instituto Evandro Chagas

Igor Brasil Costa

Instituto Evandro Chagas

Thais Letícia dos Santos Corrêa

Manchester Metropolitan University

Beatriz Monteiro Rodrigues Coelho

Amazon University

Alessandra Alves Polaro

Instituto Evandro Chagas

Amanda Emanuelle Santos da Silva

Instituto Evandro Chagas

Francisco Lúzio de Paula Ramos

Instituto Evandro Chagas

Arnaldo Jorge Martins Filho

Instituto Evandro Chagas

Jose Luiz Furtado Monteiro

Universidade do Estado do Para

Rita Catarina Medeiros Sousa

Universidade Federal do Para

Research article

Keywords: EBNA3C gene, EBV1, EBV2, infectious mononucleosis

Posted Date: October 25th, 2019 
DOI: https://doi.org/10.21203/rs.2.10515/v4

License: (c) (1) This work is licensed under a Creative Commons Attribution 4.0 International License. Read Full License 


\section{Abstract}

Background: Two types of Epstein Barr virus (EBV1 and 2) have been shown to infect humans. This study aimed to detect the types of EBV that cause infectious mononucleosis and correlate these viral types with clinical parameters in the metropolitan region of Belém from 2005 to 2016.

Methods: A total of 76 cases of infectious mononucleosis (IM) were processed at the Instituto Evandro Chagas, Ananindeua, Brazil. PCR was used to analyze the EBNA 3C region for the recognition of EBV types. Biochemical testing (aspartate aminotransferase (AST), alanine aminotransferase (ALT) and gamma-glutamyl transferase (GGT) was performed by the COBAS INTEGRA clinical biochemistry PLUS 400 / ROCHE automatic analyzer. The data were evaluated using the Statistical Package for Social Science - SPSS 17.0 and GraphPadPrism 7.0 for Windows.

Results: EBV1 infection was observed in 71.1\% (54/76) of individuals, among whom those > 14 years constituted $66.7 \%$ (36/54); the average age was 23 years, and the number of women infected was higher $(61.1 \%$ [33/54]) than that of men 38.9\%[21/54]). The symptoms/clinical signs observed in infection by EBV1 were cervical lymphadenopathy in 64.8\% (35/54), fever in 63\% (34/54), headache and arthralgia in $20.3 \%$ (11/54), and exanthema in 18.5\% (10/54). Infection by EBV2 was observed in only $17.1 \%(13 / 76)$ of cases. Coinfections by EBV1 and EBV2, most frequently showing symptoms of fever and cervical lymphadenopathy, occurred in $66.7 \%(6 / 9)$ and $55.6 \%$ (5/9) of individuals. Alterations to AST were confirmed in $14.8 \%$ (8/54), EBV2 of cases in $7.7 \%(1 / 13)$ in EBV1 infection.

Conclusions: EBV1 was predominant in $71 \%$ of clinical cases of infectious mononucleosis. The correlation of biochemical parameters in infection by EBV1, EBV2, and coinfections by EBV1/2 revealed a statistically significant difference in mean changes of EBV1 in individuals older than 14 years.

\section{Background}

Epstein Barr virus (EBV) belongs to the order Herpesvirales, family Herpesviridae, subfamily Gammaherpesvirinae, genus Lymphocryptovirus and species Human gammaherpesvirus 41. EBV was the first oncogenic virus found to infect humans 2,3. The hexagonal nucleocapsid viral particles were formed with linear, double stranded, enveloped DNA, with a diameter of 180 to $200 \mathrm{~nm} 4$.

Although symptomatic infections with these viruses occur in benign form, EBV has been implicated in the genesis of a variety of lymphoproliferative disorders and severe epithelial neoplasms, such as African Burkitt's lymphoma 5, carcinoma and nasopharyngeal 6.

In Brazil, several studies have recorded the high frequency of antibodies in the studied populations. Studies conducted by Monteiro et al. (1998) found that at least $70 \%$ of the serum samples analyzed in 
the city of Belém, state of Pará, contain IgG antibodies to EBV, at the outpatient clinic level ranging from $53.8 \%$ to $95.6 \%$, or in the community $(81.1 \%$ to $100 \%) 7$.

Positive indexes were expressive, even in the youngest lowest age groups. These results suggest that active and recent infection (infectious mononucleosis) was detected in 10.6\% (25/234) of children and adolescents in northern Brazil 8.

Data from Young and Murray (2003) demonstrated that EBV is present in approximately $90 \%$ of individuals and is controlled by the immune system, mainly by cellular immunity, which may make the subject more susceptible to virus proliferation and may trigger lymphoproliferative disorders 9,10.

It is increasingly important to identify the epidemiological characteristics associated with the risk of EBV infection in populations to reduce the clinical conditions associated with possible morbidity and mortality 11.

The difference between the sequences encoding EBV nuclear antigens (EBNA2, 3A, 3B, and 3C) allows for the identification of different genotypes with distinct epidemiological characteristics 12 .

According to Young et al. (2000), human and geographic assemblages can influence the distribution of EBV genotypes 1 and 2, which change with rates of detection of these viral genotypes in diseases associated with EBV 13. Type 1 EBV has a higher incidence in western regions, and type 2 is found more frequently in sub-Saharan Africa and New Guinea than in other parts of the world 14.

The phenotypic difference between EBV1 and 2 is more evident during immortalization of B cells in EBV1 lymphoblastoid cell lines (LCLs) compared to EBV2. This fact reinforces the biological and functional difference between the two viral types, where B cell immortalization in vitro was shown to be more effective by type 1 EBV 15. According to Mandell et al. (2001), differentiation of genotypes can clarify the different immune responses during viral persistence 16.

The objective of this study was to detect the types of Epstein-Barr virus (EBV1 and EBV2) that cause infectious mononucleosis (IgMVCA/EBV+) and correlate them clinical to biochemical parameters (ASL, ALT and GGT) from the metropolitan area of Belém between 2005 and 2016.

\section{Material And Methods}

The current study was descriptive and retrospective. Samples from 76 clinical cases of infectious mononucleosis that were reactive to EBV/VCA IgM, were tested by the RIDASCREEN® (R-Biopharm, Darmstadt, Germany) enzyme immunoassay kit and processed in the Virology section and the biochemical dosages (AST, ALT and GGT) were processed in the pathology section of the Evandro Chagas Institute, Ananindeua, Brazil, from the metropolitan area of Belém. The samples were collected between 2005 and 2016 and later evaluated by PCR for the EBNA3C gene for recognition of EBV types.

Nucleic acid extraction 
Samples were extracted using the QIAamp DNA Mini Kit (Qiagen, Germantown, MD) according to the manufacturer's protocol.

Identification of the EBV EBNA3C gene

For the identification of EBV type, we used the EBNA-3C primer 17. Due to the flanking regions of the type-specific variation primary sites, the resulting PCR products were of two different sizes for EBV1 (153 bp) and EBV2 (246 bp). Five microliters of the eluted ADN were used for PCR amplification with a primer concentration of $0.05 \mu \mathrm{M}$ (5' GCCAGAGGTAAGTGGACTTT 3' and 5' TGGAGAGGTCAGGTTACTTA 3', respectively). PCR was performed in $0.5 \mathrm{~mL}$ microcentrifuge tubes in a final $25 \mu \mathrm{L}$ mixture containing $0.125 \mu \mathrm{L}(5 \mathrm{U} / \mu \mathrm{L})$ Platinum Taq DNA Polymerase (Invitrogen ${ }^{\mathrm{TM}}$, Brazil), $1.5 \mathrm{mM} \mathrm{MgCl} 2$ (Invitrogen $^{\mathrm{TM}}$, Brazil), $0.2 \mathrm{mM}$ dNTPs (Invitrogen ${ }^{\mathrm{TM}}$, Brazil), $5 \mu \mathrm{L}$ of 10X buffer (Invitrogen ${ }^{\mathrm{TM}}$, Brazil) and $2 \mu \mathrm{L}(20 \mu \mathrm{M} / \mu \mathrm{L}$ ) of the abovementioned primers. After denaturation of the DNA mold at $94^{\circ} \mathrm{C} / 1 \mathrm{~min}, \mathrm{PCR}$ cycle conditions (PTC 100 / Peltier Effect Cycle, Thermostable Controller) included 40 cycles of denaturation at $94^{\circ} \mathrm{C} / 30 \mathrm{sec}$, annealing at $58^{\circ} \mathrm{C} / 30 \mathrm{sec}$, extension at $72^{\circ} \mathrm{C} / 1 \mathrm{~min}$, after $1 \mathrm{final}$ extension cycle at $72^{\circ} \mathrm{C} /$ 7 min. Water (negative control) and B958 and P3HR1 cell lines (positive controls) were used for the amplification of EBV1 and EBV2 in each amplification series.

Ethical considerations

The research study was approved by the research ethics committees of the Evandro Chagas Institute (CAAE $n^{\circ}$ 65332717.2.0000.0019, with legal opinion n² 2098453, dated June 4, 2017).

Statistical analysis

The results were organized and stored in a database in Microsoft Office Access 2016, Statistical Package for Social Science-SPSS 17.0. A $p$ value of less than 0.05 was considered significant.18.

\section{Results}

Detection of EBNA3C gene of the EBV infectious IM.

EBV DNA was detected in 76 patients with infectious mononucleosis (IM) by PCR for the EBNA3C gene. In total, $55.3 \%$ (42/76) were female, and $44.7 \%$ (34/76) were male. The patients were from the cities of Belém with 76.3\% (58/76), Ananindeua with 22.4\% (17/76) and Marituba with 1.3\% (1/76).

As for the clinical picture, a multiplicity of signs and symptoms were noticed, such as fever in $65.8 \%$ (50/76), cervical lymphadenomegaly in $60.5 \%$ (46/76), pharyngitis in $19.7 \%(15 / 76)$, arthralgia in $17.0 \%$ (13/76), and headache in $9.2 \%$ (7/76). For fever days, 22\% (11/50) reported their permanence for up to 5 days, $16 \%$ (8/50) for 10 days, $20 \%$ (10/50) for 15 days, $16 \%$ (8/50) for 20 days, $16 \%(8 / 50)$ for more than 20 days, and $10 \%(5 / 50)$ had no information in the epidemiological record. 
EBV1 infection was observed in $71.1 \%$ (54/76); the most frequent age group was $>14$ years old, with $66.7 \%(36 / 54)$ of the individuals. Since the age range was 23 years, the number of women was $61.1 \%$ $(33 / 54)$, which was higher than in men, with $38.9 \%(21 / 54)$.

Regarding the origin of the individuals with EBV genotype 1, the frequencies were as follows: city of Belém with 76.0\% (41/54), Ananindeua with 22.2\% (12/54) and Marituba with 1.8\% (1/54).

The symptoms/clinical signs observed in infection by EBV1 were cervical lymphadenopathy in $64.8 \%$ $(35 / 54)$, fever in $63 \%(34 / 54)$, headache and arthralgia in $20.3 \%(11 / 54)$, and exanthema in $18.5 \%$ (10/54) (Fig 1).

In EBV2 infection, 17.1\% (13/76) cases were observed, where the most frequent symptom was fever in $76.9 \%(10 / 13)$. The individuals were distributed in only two ranges, being $>14$ years old, with $53.8 \%$ $(7 / 13)$ individuals, compared to 6 to 14 years old, in $46.2 \%(6 / 13)$ individuals; the average age was 24 years, with the males being more frequent $76.9 \%(10 / 13)$ than females $23.1 \%(3 / 13)$.

Confection with EBV1 and EBV2 is more frequent in children and cervical lymphadenopathy in 66.7 (6/9) and $55.6 \%$ (5/9), respectively. The most frequent age group was $>14$ years, with $44.4 \%(4 / 9)$ of the individuals. Since the age group of 2 to 5 years presented 22.2\% (2/9) individuals and 6 to 14 years with $33.3 \%(3 / 9)$ individuals, with an average age of 21 years, the number of women of $66.7 \%(6 / 9)$ was higher than that of men with $33.3 \%(3 / 9)$.

In the assessment of hepatic function, alterations to AST in EBV1 infection were confirmed in $14.8 \%$ $(8 / 54)$ of cases with results above the reference values (5-40 U/L) and 7.7\% (1/13) for EBV2. When analyzing the mean values by age group, the range of $>14$ years was outside the normality limits with a higher frequency of alterations, thus presenting a statistically significant difference ( $p$-value $<0.05)$, (Table 1).

Values above the reference values (2-41 U/L) were also observed for ALT. The mean value was outside the limits of normality in the age groups of 6 to 14 years and $>14$ years, presenting a significant difference $(p$-value $<0.05)$ by the Wilcoxon test, (Table 1$)$.

For the evaluation of GGT, some altered results were observed, but no changes were found in the age group of 2 to 5 years, given the reference values: ( $5-55 \mathrm{U} / \mathrm{L}$ ). Changes in the age group from 6 to 14 years were all above normal, given the same reference range of the previous age group, and the greatest number of alterations was observed in the range of $>14$ years, above or below, given reference values: (12 - $43 \mathrm{U} / \mathrm{L}$ ) (Table 1). The mean value was outside the limits of normality in the age group of $>14$ years, and the mean values presented a significant difference $(\mathrm{p}$-value $<0.05)$ by the Wilcoxon test.

\section{Discussion}

Primary EBV infection is usually asymptomatic and may progress to benign lymphoproliferative disease called infectious mononucleosis (IM), especially in late childhood or early adulthood in developing 
countries 4 .

Infectious mononucleosis is characterized by significant clinical polymorphisms in which factors such as age, immune status and comorbidities have been described as parameters in clinical evolution from asymptomatic infections to more severe conditions evidenced by acute complications, such as multiple organ failure, disseminated intravascular coagulation, ulcer/perforation of digestive tract, coronary artery aneurysm, lymphomas and lymphohistiocytes and EBV-associated hemophagocytosis 19, 20.

Mendoza et al. (2008) confirmed that EBV infection has an incubation period ranging from 4-6 weeks with prodromal symptoms of asthenia, anorexia, headache and chills, which often precede the signs and symptoms of mononucleosis: fever (that can reach $39-40^{\circ} \mathrm{C}$ ) accompanied by pharyngotonsillitis and lymphadenopathy $21,22,23$. In agreement, in our study, fever was the clinical finding in 65.8\% (50/76), cervical lymphadenomegaly in 60.5\% (46/76), pharyngitis in 19.7\% (15/76), arthralgia in 17.0\% (13/76), and headache in $9.2 \%$ (7/76) of the 76 patients analyzed.

Regarding the type of EBV infection, there are two different types of EBV 24. EBV types are related to variation in the EBNA2 and EBNA3 gene sequences, commonly known as types 1 and $217,25$.

Studies conducted in other countries have demonstrated the predominance of EBV1 infection in China with rates of 76.3\%, Argentina in 75.9\%, Sweden in 67\% and Hong Kong 57\% 26, 27, 28, 29.

Our findings revealed that EBV1 was frequent in 71.1\% (54/76) of cases of infectious mononucleosis from the metropolitan area of Belém, Brazil. A total of 68 samples of Chinese individuals were studied with the aim of identifying circulating types according to the EBNA 3C gene by PCR. In total, 76.3\% (45/59) of samples were EBV-1, 20.3\% (12/59) were EBV-2, and 3.4\% (2/59) EBV-1 and EBV-2 (coinfected), and $13.2 \%(9 / 68)$ of the samples did not amplify.

A study conducted by Deng et al. (2014) with samples of 209 Japanese patients obtained the following results: 146/209 (69.9\%) samples had EBV, 107/146 (73.3\%) were EBV-1, 27/146 (18.5\%) were EBV-2 and 12/146 (8.2\%) were coinfected (EBV-1 and EBV-2), and 63/209 (30.1\%) did not amplify the EBNA3C gene 30 .

A study conducted in Qatar revealed similar frequencies with a predominance of EBV1 $(72.5 \%, 37 / 51)$ compared to genotype 2 (3.5\%), and mixed infections were detected in $4 \%$ of the samples 31 . The determination of the types of EBV in the present study made it possible to distinguish the molecular epidemiology and circulation of these viral agents.

The most clinically relevant transferases are aminotransferase (aspartate aminotransferase - AST, alanine aminotransferase - ALT and gamma-glutamyl transferase - GGT), which express the main indexes of liver function 32, where small changes may occur in normal individuals (less than twice the reference value). In patients with infectious mononucleosis caused by EBV, values up to 5 to 10 times higher than the reference values have been reported and may even progress to fulminant hepatitis, which is not present with bilirubin abnormalities 33,34 . 
Ninety-five patients with infectious mononucleosis and 95 healthy controls were analyzed for AST, ALT and GGT; alterations were elevated in patients with infectious mononucleosis compared to the controls 34 .

When compared to the EBV types (EBV1, EBV2 and EBV1/2), our results were statistically significantly correlated with the age group and AST and ALT values $(p<0.005)$. Similar data were cited by Zhang et al. (2018), who reported that ALT, AST and GGT levels were significantly increased in cases of infectious mononucleosis compared to controls, indicating that transferase levels can be used to diagnose and treat as a risk alert for the infection caused by MI34.

\section{Conclusion}

This pioneering study identified EBV1 in $71.1 \%$ of clinical cases of infectious mononucleosis in the metropolitan area of Belém, Pará, from 2005 to 2016. In 11.8\% of the cases, coinfections with EBV1 and EBV2 occurred. Cervical lymphadenopathy and fever were the most relevant clinical findings and signs in the EBV types. The correlation of biochemical parameters (AST, ALT and GGT) with type of infection by EBV1, EBV2, and by EBV1/2 revealed a statistically significant difference in mean changes of EBV1 in individuals older than 14 years.

\section{Abbreviations}

EBV: Epstein-Barr virus; LCLs: lymphoblastic cell lines; AST: aspartate amino transferase; ALT: alanine amino transferase; GGT: gamma-glutamyl transferase: MI: infectious mononucleosis.

\section{Declarations}

\section{Acknowledgments}

We are grateful to all the individuals who contributed to the development of this study, especially Antonio de Moura and Manuel Gomes.

\section{Availability of data and materials}

All data generated or analyzed during this study are included in this published study. No other data are available for supplementary materials.

\section{Authors' contributions}

The work presented here was carried out as a collaboration between all authors. TAFM, IBC, IBC, TLSC, BMRC, AAP, AESS, FLPR, and AJMF carried out most experiments. TAFM and JLFM made contributions to design, data analysis and data interpretation. TAFM and RCMS drafted the manuscript. JLFM and TAFM provided the most financial support. TAFM, AAP and AESS collected and assembled the data. All the authors have given final approval to publish the manuscript. 


\section{*Corresponding author}

Correspondence to Talita A. F. Monteiro

\section{Competing interests}

There authors declare that there are no competing interests.

\section{Funding}

The authors received no specific funding for this work.

\section{Consent for publication}

All authors of this article have directly participated in the planning and drafting and all authors listed have read and approved the final version including details and images. The written informed consent for the publication has been obtained from all the authors. The patients, parents, and legal guardians were informed about the publication and had signed informed consent forms.

\section{Ethics approval and consent to participate}

All participants provided informed written consent for all study procedures and for the use of their data for scientific evaluation and publication in a blinded form. This study was conducted in accordance with the Declaration of Helsinki, and it was approved by the Evandro Chagas Institute with legal opinion $\mathrm{n}^{\circ}$ 2098453, dated June 4, 2017.

\section{References}

1. International Committee on Taxonomy of Viruses (ICTV). The Online (10th) Report of the ICTV, 2017. https://talk.ictvonline.org/ictv-reports/ictv_online_report/.

2. Rickinson AB, Kieff ED. Epstein-Barr virus and its replication. In: Fields virology Edited by: Fields BN, Knipe DM, Howley PM. 2007, Philadelphia, Lippincott, Williams \& Wilkins, pp 2603-54.

3. Javier RT, Butel JS. The History of Tumor Virology. Cancer research. 2008, v.68(19), p. 7693-06.

4. Rickinson AB, Kieff ED. Epstein-Barr Virus. In: Fields virology. Edited by: Knipe DM, Howley PM. 2007, Philadelphia: Lippincott, Williams and Wilkins; pp. 2657-701.

5. Hassan R, White LR, Stefanoff CG, Oliveira DE, Felisbino FE, Klumb CE, Bacchi CE, Seuánez HN, Zalcberg IR. Epstein-Barr Virus (EBV) detection and typing by PCR: a contribution to diagnostic screening of EBV-positive Burkitt's lymphoma. Diagnostic pathology. 2006; v.1(17), p.1-7. 
6. Wolf H, Hausen HZ \& Becker V. EB viral genomes in epithelial nasopharyngeal carcinoma cells. Nature New Biology. 1973;v.244(138), p. 245-247.

7. Monteiro TAF, Gomes MLC, Noronha VLC, Sousa MRS, Oliveira CS Gusmão, RHP, Freitas RB, Linhares AC. Prevalencia de anticorpos para o vírus de Epstein Barr (EBV) em Belém, Pará, Brasil. Revista Paraense de Medicina. 1998; v.12, (2), p. 8-12.

8. Monteiro TAF, Gomes MLC, Gusmão RHP, Oliveira CS, Freitas RB, Noronha VLC. Mononucleose infecciosa em crianças e adolescentes de Belém, Pará, Brasil: abordagem clínica e soroepidemiológica. Revista Paraense de Medicina. 1998; v.12 (3), p.34-44.

9. Young LS, Murray PG. Epstein-Barr virus and oncogenesis: from latent genes to tumours. Oncogene. 2003; v.22 (35), p. 5108-5121.

10. Fan H, Gulley ML. Epstein-Barr viral load measurement as a marker of EBV-related disease. Molecular Diagnostics. 2001; v. 6(4), p. 279-289.

11. Gulley ML, Tang W. Using Epstein-Barr viral load assays to diagnose, monitor, and prevent posttransplant lymphoproliferative disorder. Clinical Microbiology Reviews. 2010; v. 23(2), p. 350366.

12. Cohen Jl. Epstein Barr virus infection. The New England Journal of Medicine. 2010; v. 343(7), p. 481492.

13. Young LS, Dawson CW, Eliopoulos AG. The expression and function of Epstein Barr virus encoded latent genes. Molecular Pathology. 2000; v. 53(5), p. 238-247.

14. Farrell PJ. Epstein-Barr Virus Strain Variation. Current Topics in Microbiology and Immunology. 2015; 390(1), p. 45-69.

15. Rickinson AB, Young LS, Rowe M. Influence of the Epstein-Barr virus nuclear antigen EBNA 2 on the growth phenotype of virus-transformed B cells. Journal of virology. 1987; v. 61(5), p. 1310-1317.

16. Mandell GL, Bennett JE, Dolin R 2001. Principles and Practice of Infectious Disease. 5th ed Churchill Livingstone, New York, 2001; v.2, p.1364-1377.

17. Sample J, Young L, Martin B, Chatman T, Kieff E, Rickinson A, Kieff, E. Epstein-Barr virus types 1 and 2 differ in their EBNA-3A, EBNA-3B, and EBNA-3C genes. Journal of Virology. 1990; v. 64 (9), p. 40844092.

18. SPSS - Statistical Package for the Social Sciences. Base 17.0 User's Guide. 2017. https://www.taylorfrancis.com/books/9780203180990.

19. Son KH, Shin MY. Clinical features of Epstein-Barr virus-associated infectious mononucleosis in hospitalized Korean children Journal of Pediatrics. 2011; v. 54(10), p.409-413.

20. Fujiwara S, Kimura H, Imadome K, Arai A, Kodama E, Morio T, Shimizu N, Wakiguchi H. Current research on chronic active Epstein-Barr virus infection in Japan. Pediatrics International. 2014; v. 56, p.159-166. doi: 10.1111/ped.12314.

21. Mendoza N, Diamantis M, Arora A, Bartlett B, Gewirtzman A, Tremaine AM, et a Mucocutaneous manifestations of Epstein-Barr virus infection. American Journal of Clinical Dermatology. 2008; v. 
9(5), p. 295-305.

22. Luzuriaga K, Sullivan JL. Infectious mononucleosis. The New England Journal of Medicine. 2010; v. 362, p.1993-2000.

23. Tattevin P, Le Tulzo Y, Minjolle S, Person A, Chapplain JM, Arvieux C, Thomas R, Michelet C. Increasing incidence of severe Epstein-Barr virus-related infectious mononucleosis: surveillance study. Journal of Clinical Microbiology. 2006; v.44(5), p.1873-74.

24. Cho Y, Gordadze AV, Ling PD, Wang F. Evolution of two types of Rhesus lymphocryptovirus similar to type 1 and type 2 Epstein-Barr virus. Journal of virology. 1999; v. 73(11), p. 9206-12.

25. Dambaugh T, Hennessy K, Chamnankit L, Kieff E. U2 region of Epstein-Barr virus DNA may encode Epstein-Barr nuclear antigen 2. Proceedings of the National Academy of Sciences of the United States of America. 1984; v. 81(23), p. 7632-36.

26. Cui Y, Wang Y, Liu X, Chao Y, Xing X, Zhao C, et al. Genotypic analysis of Epstein-Barr virus isolates associated with nasopharyngeal carcinoma in Northern China. Intervirology, 2011; v. 54, p. 131-138.

27. Correa RM, Fellner MD, Alonio LV, Durand K, Teyssié AR, Picconi MA. Epstein-barr virus (EBV) in healthy carriers: Distribution of genotypes and 30 bp deletion in latent membrane protein-1 (LMP-1) oncogene. Journal of Medical Virology. 2004; v.73(4), p. 583-588.

28. Falk KI, Zou J, Lucht E, Linde A, Ernberg I. Direct Identification by PCR of EBV Types and Variants in Clinical Samples. Journal of Medical Virology. 1997; v. 51(4), p. 355-363.

29. Srivastava GK, Wong KY, Chiang AK, Lam KY, Tao Q. Coinfection of multiple strains of Epstein-Barr virus in immunocompetent normal individuals: reassessment of the viral carrier state. Blood. 2000; v. 95(7), p. 2443-45.

30. Deng Z, Uehara T, Maeda H, Hasegawa M, Matayoshi S, Kiyuna A, Suzuki, M. Epstein-Barr virus and human papillomavirus infections and genotype distribution in head and neck cancers. PLoS ONE. 2014; 10(3): e0118439. doi:10.1371/journal.pone.0118439.

31. Smatti MK, Yassine HM, AbuOdeh R, AlMarawani A, Taleb SA, Althani AA, Gheyath K. Nasrallah GK.Prevalence and molecular profiling of Epstein Barr virus (EBV) among healthy blood donors from different nationalities in Qatar. PLoS One. 2017; 12(12):e0189033.

32. Herbinger KH, Hanus I, Felbinger TW, Weber C, Beissner M, Von Sonnenburg F, Löscher T, Bretzel G, Nothdurft HD, Hoelscher M, Alberer M. Elevated values of clinically relevant transferases induced by imported infectious diseases: A controlled cross-sectional study of 14,559 diseased german travelers returning from the tropics and subtropics. American Journal of Tropical Medicine and Hygiene. 2016; v.95(2), p. 481-487.

33. Vouloumanou EK, Rafailidis PI, Falagas ME. Current diagnosis and management of infectious mononucleosis. Current Opinion in Hematology. 2012; v. 9(1), p.14-20.

34. Zhang L, Zhou P, Meng Z, Pang C, Gong L, Zhang Q, Jia Q, Song K. Infectious mononucleosis and hepatic function. Experimental and Therapeutic Medicine. 2018; v.15(3), p. 2901-2909.

\section{Table 1}


Due to technical limitations regarding pdf files, Table 1 can be found in the supplemental file section. Table 1. Biochemical parameters in EBV 1 and EBV 2 infections in clinical cases of infectious monomucleosis, 2005-2016.

\section{Figures}

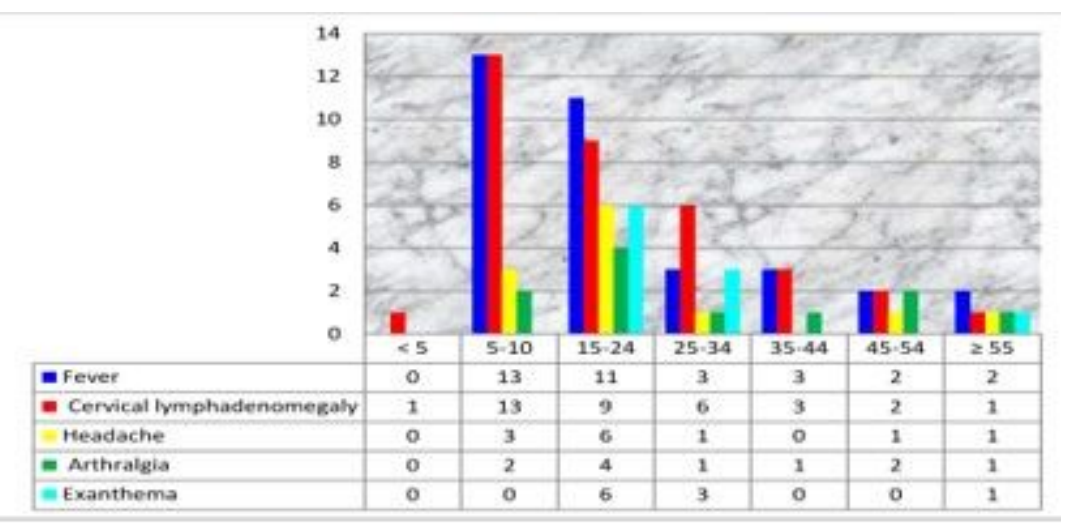

\section{Figure 1}

Signs and symptoms of infectious mononucleosis in patients infected with EBV-1, 2005 to 2016.

\section{Supplementary Files}

This is a list of supplementary files associated with this preprint. Click to download.

- Tab1TalitamonteiroBMC24102019.pdf 